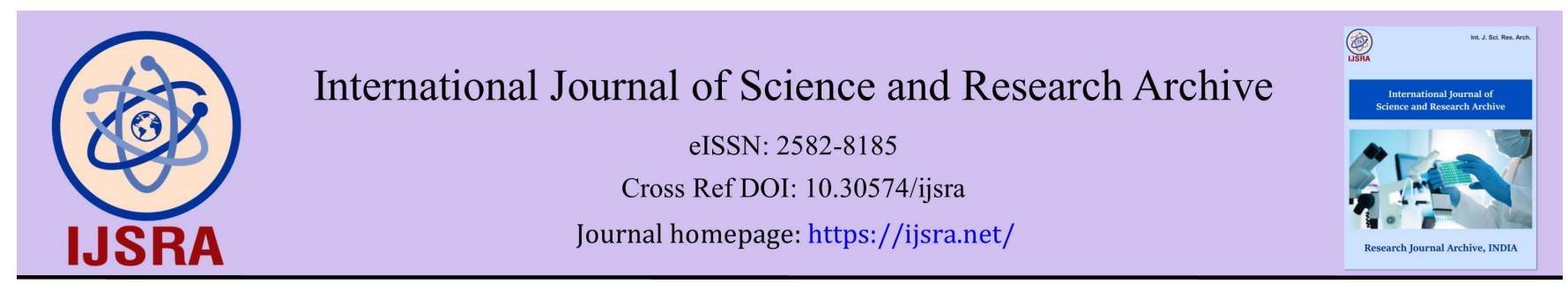

(REVIEW ARTiCle)

\title{
Global market and organizational management: A brief theoretical essay
}

\author{
Fabricio Quadros Borges ${ }^{1, *}$ and Silvane Vatraz ${ }^{2}$ \\ ${ }^{1}$ Federal Institute of Pará, Brazil. \\ ${ }^{2}$ Rural Federal University of the Amazon, Brazil.
}

International Journal of Science and Research Archive, 2021, 03(02), 151-156

Publication history: Received on 05 September 2021; revised on 06 October 2021; accepted on 08 October 2021

Article DOI: https://doi.org/10.30574/ijsra.2021.3.2.0157

\begin{abstract}
The objective of this investigation is to analyze the globalization process in order to verify its effects on the organizational management environment. Globalization is a process endowed with technological, social, economic and cultural transformations, which involve increased communication and interdependence between countries that bring together world markets, societies and cultures. The article questions about the way in which the transformations were reflected in the organizational management environment. The methodology used a bibliographic survey and an analysis that associated the dynamics of the globalization process and great representatives of administrative thought. The study inferred that the changes resulting from the globalization process were absolved by management models according to organizational demands and in certain circumstances.
\end{abstract}

Keywords: Global market; Structure; Internationalization; Management demands; Organizations

\section{Introduction}

The global market dynamic, characterized as globalization, comprises a process endowed with technological, social and cultural scale, which involves increased communication and interdependence between countries that bring together world markets, societies and cultures [1]. In a time of organizational complexities, uncertainties in resource management and a market environment inserted in this globalization process, the challenge of understanding the consequences of globalization in the business administration environment represents one of the most important scientific commitments of capitalist society.

Globalization actually comprises the extension of an organization to gradually wider environments through the end of national economies and an ever-increasing integration of markets, means of communication and transport [2].

The aim of this article is to develop possibilities for interpreting the globalization process in order to observe its effects on the Business Administration environment. In this perspective, this study intends to question how the transformations arising from globalization were reflected in the environment of Business Administration. It is based on the hypothesis that when the fundamental theoretical advances in the evolution of Administration are elucidated in light of current realities, reasonable conditions are created to interpret the objectives proposed by organizations and to raise subsidies for the transformation of these objectives into organizational actions through planning, organization, direction, control and coordination.

\footnotetext{
${ }^{*}$ Corresponding author: Fabricio Quadros Borges

Federal Institute of Pará, Brazil.

Copyright $(2021$ Author(s) retain the copyright of this article. This article is published under the terms of the Creative Commons Attribution Liscense 4.0.
} 


\section{Material and methods}

The investigation is classified regarding the approach to the problem as qualitative research and regarding its gender as a theoretical study. It is qualitative, as it seeks to provide a better view and understanding [3] about the globalization process. It is theoretical insofar as it analyzes the intrinsic correlation between globalization and the effects on Business Administration. The methodology was divided into two stages: data collection and analysis.

Data collection was carried out through a bibliographical survey, through books and periodicals that address the theme. The collection process took two directions: the globalization process and the evolution of administration in light of globalization. Data processing sought to associate political, economic and cultural aspects of the global market and organizational demands. Data analysis, in turn, had the purpose of examining the environment of Business Administration from the transformations arising from the globalization process.

\section{Global Market}

The global market finds itself in a globalized environment. Globalization comprises a global integration process that is based on economic liberalization. Through the gradual elimination of tariff barriers that protect a given production from foreign competition, countries open themselves to the international flow of goods, services and capital [2]. This environment causes the growth of transnational corporations, which play a decisive role in the international economy.

In this discussion, globalization is presented as a contextual environment, as it gathers conditions to act on the space inherited from past times, comprising organizational approaches built through the evolution of administrative thinking, remodeling them according to new market needs. Globalization presents itself through three spheres that must be analyzed together.

In the political sphere, political globalization only makes sense if it is accompanied by global justice, based on a system of legally binding world rules, conflict resolution and collective enforcement. It is believed that global justice must be fair, and this is not necessarily advocated by all nations and all people in the current phase of globalization [1].

The economic sphere comprises a process that tends to remove barriers that countries still maintain to the free movement of capital and goods. This process is notably driven by transnational corporations and international centers of economic power such as the World Bank or the International Monetary Fund. The essential tool will be new communication technologies, such as the Internet [1].

In the cultural sphere, it stands out that, despite opportunities for cultural enrichment, the reality is that, despite a marginal miscegenation being present in our societies, our cities are increasingly similar, our leisure patterns are also the same, our eating and clothing habits follow the same pattern, with an alarming preponderance of the American way of life, which threatens to become the only planetary form of life [4].

The differential nature of world development is not an attribute of the deepening of the international division of labor (support material for globalization), it is implicit in the very nature of the global capitalist accumulation system, which, by definition, presupposes the concentration of power, wealth and knowledge in a small group of highly developed countries, while other countries must be inserted from the rules developed by transnational capital [5].

Faced with this reality, the least developed countries must concentrate all their efforts on finding ways to effectively use the advantages that the current international division of labor can offer, especially those related to new technologies, despite being controlled by the developed production centers. of knowledge, it is possible to adapt to regional and local conditional [6].

It appears that the globalization process has gradually undergone an intensification, notably in the 1990 s and 2000 s. This began with the emergence of capitalism: Since the emergence of capitalism, there has always been a tendency towards internationalization, mainly due to its essence: producing for the market aiming at profit and, consequently, the accumulation of wealth [7].

The internationalization of capitalism practically affects the entire planet and intensifies to such an extent that it deserves a special name, globalization, basically marked by the globalization of production, circulation and consumption, that is, of the entire cycle of capital reproduction. Under these conditions, the elimination of barriers between nations became a necessity, so that capital could flow smoothly [8]. 
This process can be opportunely characterized through the metaphor of the global factory. The global factory is installed beyond any and all frontiers, articulating capital, technology, labor force, division of social labor and other productive forces. Accompanied by advertising, print and electronic media, the cultural industry, mixed in newspapers, magazines, books, radio programs, television broadcasts, video clips, faxes, computer networks and other means of communication, information and fabulation, dissolve borders, streamlines markets, generalizes consumerism. It provokes the deterritorialization and new territorialization of things, people and ideas. It promotes the resizing of spaces and times $[2]$.

In general, the globalization process comprises a development phase of the capitalist system, whose characteristics such as the privatization of economies, the deregulation of markets, changes in work processes, from technological, financial, cultural and social changes. However, Amartya Sen shows that globalization, with the contemporary capitalism of Western countries in Europe and North America, has imposed rules on trade and global relations that oppress the poorest in the world and is much more concerned with the expansion of relations of market than with democracy, elementary education or the social opportunities of the subaltern sectors [9]. And there is also the permanent conflict between the economic powers that encourage global integration and the political forces that defend the borders of the nation-state.

Globalization has characteristics in its transforming dynamics. New information technologies are integrating the world into global networks of instrumentality. Computer communication generates a vast array of virtual communities; a new form of relationship between economy, State and society was introduced in a variable geometry system, due to the capacity of certain activities to work in real time; in the world of global flows of wealth, power and images, the search for collective or individual identity, attributed or constructed, becomes the fundamental source of social meaning; the social and political tendency is the construction of social and political action, around primary identities, so they are attributed or rooted in history and geography or are of recent construction in the search for meaning and spirituality; the first historical stages of computerized societies seem to be characterized by the pre-eminence of identity as an organizational principle; identity is becoming the main and sometimes the only source of meaning in a historical period characterized by a wide disorganization of organizations, delegitimization of institutions, disappearance of the main social movements and ephemeral cultural expressions; the State plays an important role in the relationship between technology and society, as it holds, triggers or directs technological innovation; the capacity or incapacity of societies to dominate technology, and in particular those that are strategically decisive in each historical period, largely defines their destiny; the world is truly multicultural and interdependent that we can only understand and change from a plural perspective that articulates cultural identity, global interconnectedness and multidimensional politics [10].

\section{Organizational management demands}

The German economist Karl Marx, in the mid-nineteenth century, argued that capitalism replaced the self-sufficiency and isolation of nations with a universal circulation, a general interdependence of countries; as a result, capitalism tended to nullify space through time, that is, to reduce to a minimum time taken by movement from one place to another. At this point, the question is: to annul space through time, through the contraction of time, wouldn't it be exactly the tendency to intensify the computerized means of communication? If globalization is a term that designates the end of national economies and the ever-increasing integration of markets, means of communication and transport, wouldn't Marx have foreseen what we call today the globalization of markets?

On bolder reflection, perhaps Marx would have found inspiration in the contributions of the Liberal Economists in the eighteenth century. The basic ideas of Liberal Economists constitute the initial germs of administrative thought today [2]. Adam Smith, Scottish economist, one of the most eminent theorists of Classical Economics, already visualized the principle of specialization of workers in a needle manufacture and already emphasized the need to rationalize production, which would be called the division of labor [4].

The more detailed approach to work through the study of times and movements provided a reordering of procedures in industries, and the Division of Labor understands in this context a consequence of the attempt to increase production through tasks, the main challenge of the time. It was precisely this emphasis on tasks that founded the School of Scientific Management on the efforts of Frederick Taylor [2]. His works cover a system of norms aimed at controlling the movements of man and machine in the production process, including proposals for payment for the performance of workers.

In this panorama, Henry Ford, one of the forerunners of Scientific Administration, formulates a set of production rationalization methods, which was dedicated to producing a type of product, through a vertical structure of production, coming to dominate not only raw materials, but even the transport of your products. The work was highly specialized, 
with each worker performing only one type of task. However, he did not admit specialists in Administration nor did he want university graduates on his staff [4].

The mechanistic division of labor, seen as the driving force of the system, was the main factor in the misconduct of the classics in the development of Administration as a science. When referring to the present and trying to contextualize this theoretical discussion, it is observed that globalization is a process through which the world space acquires unity. Since the beginning of the second half of the 20th century, this unit represented a necessity for the visualization of organizations. The emphasis previously given to tasks gave way to structure; we were faced with the Structuralist Theory of Administration.

The definition of Structure is equivalent to the internal analysis of a totality in its constitutive elements and their relations to each other; in addition to its totalizing aspect, structuralism is fundamentally comparative [11, 12]. Structuralism is concerned with the whole and with the relationship of the parts in the construction of the whole. In this sense, Structuralism highlights the issue of the interaction of social groups within an organization and focuses on the study of this interaction in relation to the set of organizations in the environment of society, as a unit.

Structuralism would be another method of analysis, which consists of building explanatory models of reality, called structures $[13,14]$. According to the author, structure is understood as an abstract system in which its elements are interdependent and which allows, verifying the facts and relating differences, in order to describe their order.

Structuralism constitutes a movement of thought, a new way of relating to the world. The structuralist theoretical current gained strength in the following decades, especially in the 1950s and 1960s, in opposition to the existentialism of Jean-Paul Sartre, a predominant theory throughout the 1940s and 1950s, having as one of its principles the confrontation of reason, hegemonic at that time, jettisoning the subject from the privileged place he occupied [7]. The focus of structuralism was the study of organization in a broad and integral sense, in order to consider the totality of facts with internal and external interference, and directing them to a comparative analysis [11]. Thus, the study recognizes that organizational phenomena interconnect, interpenetrate and interact in such a way that any change in a given sector of the organization affects all other sectors [11].

The character of unity attributed to organizations was gradually transferred to the entire world market due to a need to integrate commercial relations. This context was exactly what the German biologist Ludwig Von Bertalanffy [9] needed to elaborate the General Systems Theory. According to this Theory, systems cannot be understood only by the separate and exclusive analysis of each of their parts. Thus, they are based on an understanding of the mutual dependence of all disciplines and the need for their integration [4].

In this way, it is understood why the various branches of knowledge began to treat their study objectives properly by systems. The context of economic globalization demands an integration of economic agents within a competitive market reality, which requires a more real conception of the intricacies of all activities so that they can be better evaluated within a modern and dynamic as we live. Therefore, research and organizational development works are resorting to studies of the systemic approach as support and reference to better meet the demands of these economic agents through a better interpretation of organizational objectives.

Managers, in this systemic context, need to deal with challenges and within a social system they cannot control. This does not relieve them of their responsibility to provide guidance to the organization. The vision of the stability and flexibility of a social system as a consequence of its dynamic equilibrium suggests a corresponding conflict resolution strategy [2]. In every organization and in society, conflicts and contradictions invariably arise that can be resolved to the benefit of one side or the other. Thus, it takes stability and change, order and freedom, tradition and innovation, planning and laissez-faire [2].

The systems-oriented manager knows that contradictions within an organization are signs of variety and vitality, and thus contribute to the system's viability. Without conflicts, there can be no development [2]. He needs to take both terms of a contradiction into account, knowing that both will be important depending on the context. He will not try to resolve inevitable conflicts through hard decisions, but dynamically balancing the two sides [2].

However, the speed of change and the challenges of the globalized world demonstrate a need to consider circumstances; we were facing the contingency approach of the Administration. In this, organizational effectiveness would not be achieved following a single and exclusive organizational model. Thus, there would not be a single and better way to manage different goals of organizations within a varied environment. Studying this varied environment, British industrial sociologist Joan Woodward concluded that organizational design is affected by the technology used by the 
organization. Technology, as it permeates all industrial activity and participates in all types of human activity, in all fields of activity, increasingly shows that organizations use some form of technology to achieve their goals by performing tasks [4].

The origin of this entire global panorama lies in a very old process, which continues to expand. Globalization is not a recent phenomenon, and the political and economic geography of the world in which we live is the result of this process. The starting point of this process, which dates back to the great European navigations of the 15th and 16th centuries and is approached by Karl Marx in the 19th century, based on preliminary analyses, is faced in the 1990s with the emergence of the information age, thanks to the great impact caused by technological development and information technology. Emphasis began to be based on quality, productivity, competitiveness, the customer and globalization. The arrival of the information age brought a new context and an avalanche of problems for organizations; the speed and intensity of the changes went beyond what was expected [6].

Given this context, the question is which path this discussion will take, regarding its objectives regarding the creation of reasonable conditions for the interpretation of organizational objectives and regarding the subsidies for the formulation of more effective organizational actions? Henry Ford might have taken the initiative to reduce inventories to a minimum, making sure that his products were paid to the company before the raw material payment deadline.

Adam Smith, possibly, could never have foreseen that his division of labor today would be much more committed to intentional planning to intensify the achievement of objectives - as perhaps the structuralists would suggest regarding the questioned solution - than to the specialization of tasks alone. Joan Woodword perhaps defended the idea of a continuous production, from a standardized and linearly arranged processing, with intensive technology and specialized personnel. This scenario would provide a more predictable, sequential and compatible production with the challenges of globalization. This challenge presents as a consequence for the administration of organizations: the administration of uncertainty [6].

The accelerated changes, the growth of organizations, the competition held by these organizations, technological development, the economic phenomena of inflation and the internationalization of activities, require new forms and models of organization, which, according to this author, should seek a mentality compatible with the new challenges of the current market. However, today it appears that the solution lies in extreme and quick measures for the pursuit of survival and excellence. We are talking here about the Administration fads, such as: continuous improvement, total quality, benchmarking, reengineering, among others.

In any case, many seeds of these so-called emerging solutions can be compared to the possible organizational actions of great precursors of the administrative theories mentioned here. Thus, it appears that the Administration's task, which is to interpret and achieve objectives, comprises a process of managing business resources, according to emphases that best meet the organizational demands at a given time and in a given situation, which only can be understood from the knowledge of all its intricacies and locational specificities of the market.

\section{Conclusion}

The study found that the changes resulting from the globalization process were absolved by management models according to organizational demands and in certain circumstances. Insofar as globalization comprises a process of world integration based on economic liberalization, where nations are included in the international flow of goods, services and capital. This panorama causes the growth of transnational corporations, which assume a relevant role in the international economy.

It was also found that the globalization process, as a development phase of the capitalist system, presented characteristics such as the privatization of economies, the deregulation of markets, changes in work processes, from technological, financial, cultural and social changes.

These changes led to the need for the administration of companies to articulate alternative responses and many of them based on the emphases of administrative thinking.

The study also allowed for a reflection that enabled a conversation between the verified global reality and the logic of thought of the main currents of thought in the science of administration. This effort also sought to arouse the interest of new research that are directed to the object of study of administration, that is, organizations, in order to interpret the globalization process and create conditions for these organizations to position themselves in light of this level of development of the capitalist system. 


\section{Compliance with ethical standards}

\section{Disclosure of conflict of interest}

The authors have no conflict of interests.

\section{References}

[1] Zamora SD. Globalización. Revista contribuciones a la economía, abril 2013.

[2] Borges FQ. A evolução da administração no ambiente da globalização. Adcontar, Belém, v. 2, no 1, maio. 2001; 7 10.

[3] Malhotra NK. Pesquisa de marketing: uma orientação aplicada. Porto Alegre: Bookman. 2006.

[4] Assunção MA. de. Modelos de gestão no contexto da globalização. UNIEURO, Cadernos de Administração. no. 3, Brasília. 2003.

[5] Ballestero-Alvarez ME. Administração da qualidade e produtividade. São Paulo: Atlas. 2001.

[6] Ianni O. Teorias da globalização. Rio de Janeiro: Editora Civilização. 2002.

[7] Chiavenato I. Introdução à teoria da administração. Rio de Janeiro: Campus. 2000.

[8] George Jr. CS. História do Pensamento Administrativo. São Paulo: Cultrix. 1974.

[9] Bertalanffy LV. The Theory of Open Systems in Physics and Biology. New York: George Brasilier. 1968.

[10] Castells M. El surgimiento de la sociedad de redes. 2014. Disponível em. 2021.

[11] Dosse, F. História do estruturalismo: o campo do signo (1945/1966). Bauru: Edusc. 2007; 1.

[12] Ribeiro A. de L. Introdução à Teoria Geral da Administração: Rio de Janeiro: Campus. 2004.

[13] Salatiel JR. Estruturalismo: quais as origens desse método de análise? 2013 Disponível em. 2021.

[14] Viet J. Métodos Estruturalistas nas ciências Sociais. Rio de Janeiro: Tempo brasileiro. 1967. 